\title{
Research status and progress of the RNA or protein biomarkers for prostate cancer
}

This article was published in the following Dove Medical Press journal: OncoTargets and Therapy

\section{Chunjiao Song' \\ Huan Chen ${ }^{2}$ \\ Chunyu Song ${ }^{3}$}

'Medical Research Center, Shaoxing People's Hospital/Shaoxing Hospital, Zhejiang University School of Medicine, Shaoxing, Zhejiang Province, China; ${ }^{2}$ Key Laboratory of Microorganism Technology and Bioinformatics Research of Zhejiang Province, Zhejiang Institute of Microbiology, Hangzhou, Zhejiang, China; ${ }^{3}$ Department of Anesthesia, The Second Clinical Hospital of Harbin Medical University, Harbin, Heilongjiang, China
Correspondence: Chunjiao Song Medical Research Center, Shaoxing People's Hospital (Shaoxing Hospital, Zhejiang University School of Medicine), No 568 Zhongxing Bei Road, Shaoxing 3। 2000, Zhejiang, China Tel +86057588228687 Email chunjiaosong@163.com

\begin{abstract}
Prostate cancer is a kind of male malignancy. Recently, a large number of studies have reported many potential biomarkers for the diagnosis and prognosis of prostate cancer. In this literature review, we have collected a number of potential biomarkers for prostate cancer reported in the last 5 years. Among them, some are undergoing Phase III clinical trials, and others have been approved by the US Food and Drug Administration. However, most are still in the period of basic research. The review will contribute to future research to find the biomarkers to guide clinicians to make personalized treatment decisions for each prostate cancer patient.
\end{abstract} Keywords: IncRNAs, microRNAs, fusion gene, TMPRSS2-ERG, methylation

\section{Plain language summary}

Men have a unique malignancy, prostate cancer. Prostate cancer can be dangerous to men. Doctors and scientists have done a lot of research to detect prostate cancer. In this article, we have summarized the suggestive substances found over the years. Doctors can tell if a patient has prostate cancer by examining these substances. Some of these substances are valuable and some of them are in experiment stages. We put them all together in order to better serve doctors and patients, to enable them to know which substances can help us identify prostate cancer.

\section{Introduction}

Prostate cancer $(\mathrm{PCa})$ is a leading male malignancy all over the world, with 1.1 million new cases in 2012. Globally, the incidence rates are the highest in Australia, New Zealand, North America, Northern and Western Europe, and Caribbean countries, while the mortality rates are rising in some Asian and European countries, such as Korea, China, and Russia. ${ }^{1,2}$ In 2017, 161,360 new cases were diagnosed, and 26,730 patients were dead due to PCa in America. ${ }^{3}$ In other words, in America, 1/6 men would develop $\mathrm{PCa}$, whereas $1 / 35$ men would die from $\mathrm{PCa}{ }^{4}$

It is well known that prostate-specific antigen (PSA) screening has increased the incidence of $\mathrm{PCa}$ cases at the beginning of its application in clinical routine, and the $\mathrm{PCa}$ incidence reached the peak after decades of the application, and now the incidence of PCa has declined from the last peak and currently has a stable slope. At present, PSA is used as a test to support the diagnosis of PCa. The patients with elevated PSA will undergo further prostate biopsy. The diagnosis of PCa is usually made by biopsy outcome and histologic evaluation. The tissues obtained from biopsy or surgical resection will be examined by pathologists to observe cell morphology, organization arrangement, and to detect the expression levels of a variety of proteins using immunohistochemistry. In addition, we have other tools, such as digital rectal examination (DRE) and magnetic resonance imaging. Imaging has more value in the diagnosis of 
aggressive or metastatic $\mathrm{PCa}$, and is more commonly used for tumor staging.

Although compared with the past, the patient's diagnostic and survival rates are greatly improved, following the development of technology and science. Nowadays we are thoroughly looking forward to more sensitive and specific biomarkers in favor of accurate diagnosis and the individualized treatment for PCa. Moreover, it is also very important to find biomarkers to distinguish aggressive from indolent $\mathrm{PCa}$. In the review, we used the search terms "prostate cancer" and "biomarker" to screen literatures in PubMed and CNKI databases, and searched nearly 100 related studies. We studied these literatures carefully, and relevant data were extracted and summarized in this review and Table 1. Among them, some biomarkers were already used in commercial kits, but more molecules with potential to become markers

Table I The list of the biomarkers for prostate cancer

\begin{tabular}{|c|c|c|c|c|}
\hline Name & Full name & Predictive value & Ref & Application value \\
\hline PSA & Prostate-specific antigen & $\begin{array}{l}\text { PSA was used to assess patients' } \\
\text { response to treatments, and to predict } \\
\text { recurrence in the whole stages of PCa } \\
\text { progression }\end{array}$ & $5-7$ & $\begin{array}{l}\text { PSA was used for dynamic } \\
\text { monitoring recurrence after initial } \\
\text { treatment (FDA, 1986). PSA } \\
\text { was used in the clinic for early } \\
\text { diagnosis of PCa (FDA, 1994). } \\
\text { PSA testing was used in high-risk } \\
\text { populations (the US Preventative } \\
\text { Services Task Force, 2012) }\end{array}$ \\
\hline \multicolumn{5}{|c|}{ Long noncoding RNA } \\
\hline PCA3 & Prostate cancer antigen 3 & $\begin{array}{l}\text { The PCA3 screening might have } \\
\text { potential as a second-line test } \\
\text { used in men with high PSA levels. } \\
\text { A commercially available assay } \\
\text { combining serum PSA with urinary } \\
\text { PCA3 and TMPRSS2-ERG provided a } \\
90 \% \text { specificity and } 80 \% \text { sensitivity in } \\
\text { diagnosing PCa }\end{array}$ & 9,28 & $\begin{array}{l}\text { The PCA3 expression level was } \\
\text { detected as a diagnostic test for } \\
\text { PCa in these cases with a prior } \\
\text { negative biopsy (FDA) }\end{array}$ \\
\hline PCATI4 & $\begin{array}{l}\text { Prostate cancer-associated } \\
\text { transcript } 14\end{array}$ & $\begin{array}{l}\text { PCATI4 was highly expressed in } \\
\text { low-grade PCa and loss of PCATI } 4 \\
\text { predicted for disease aggressiveness and } \\
\text { recurrence }\end{array}$ & 11 & \\
\hline MALAT-I & $\begin{array}{l}\text { Metastasis-associated lung } \\
\text { adenocarcinoma transcript I }\end{array}$ & $\begin{array}{l}\text { The MALAT-I score was tested in } \\
\text { a discovery phase and a multicenter } \\
\text { validation phase. According to the } \\
\text { decision curve analysis, using a } \\
\text { probability threshold of } 25 \% \text {, the } \\
\text { MALAT-I model would prevent } \\
30.2 \%-46.5 \% \text { of unnecessary biopsies } \\
\text { in PSA } 4-10 \mathrm{ng} / \mathrm{mL} \text { cohorts, without } \\
\text { missing any high-grade cancers }\end{array}$ & 12 & $\begin{array}{l}\text { MALAT-I had a higher AUC } \\
\text { compared to PSA level to predict } \\
\text { the risk of PCa before biopsy } \\
\text { (a multicenter clinical trial) }\end{array}$ \\
\hline PCAI8 & Prostate cancer antigen 18 & $\begin{array}{l}\text { PCAI } 8 \text { was upregulated in PCa tissues } \\
\text { compared to BPH samples }\end{array}$ & 13 & \\
\hline PVTI & $\begin{array}{l}\text { Plasmacytoma variant } \\
\text { translocation I }\end{array}$ & $\begin{array}{l}\text { PVTI exon } 9 \text { may be associated with } \\
\text { aggressive } \mathrm{PCa}\end{array}$ & 14 & \\
\hline SChLAPI & $\begin{array}{l}\text { Second chromosome locus } \\
\text { associated with prostate-I }\end{array}$ & $\begin{array}{l}\text { The overexpression of SChLAPI could } \\
\text { independently predict biochemical } \\
\text { recurrence of PCa after RP }\end{array}$ & 15,16 & \\
\hline \multicolumn{5}{|l|}{ MicroRNA } \\
\hline miR-34a & & $\begin{array}{l}\text { The expression level of miR-34a was } \\
\text { decreased in clinical PCa samples. And } \\
\text { miR-34a might be related with PCa } \\
\text { progression and poor prognosis }\end{array}$ & 17 & \\
\hline
\end{tabular}


Table I (Continued)

\begin{tabular}{|c|c|c|c|c|}
\hline Name & Full name & Predictive value & Ref & Application value \\
\hline miR-I & & $\begin{array}{l}\text { miR-I was significantly downregulated } \\
\text { in recurrent PCa compared to } \\
\text { nonrecurrent PCa samples. The AUC } \\
\text { value of miR-I for PCa recurrence was } \\
0.885(P<0.00 I) \text { with the sensitivity of } \\
0.863 \text { and specificity of } 0.889 \text { based on } \\
\text { ROC curve analysis }\end{array}$ & 18 & \\
\hline miR-129 & & $\begin{array}{l}\text { The decrease in miR-129 expression in } \\
\text { peripheral blood mononuclear cells was } \\
\text { significantly associated with aggressive } \\
\text { clinical pathologic features such as } \\
\text { histologic grade, high preoperative PSA } \\
\text { level, pathologic stage, high Gleason } \\
\text { score, LN metastasis, angiolymphatic } \\
\text { invasion, biochemical recurrence }\end{array}$ & 19 & \\
\hline miR-2I & & $\begin{array}{l}\text { The expression of miR-2I was } \\
\text { significantly correlated with the Gleason } \\
\text { score, clinical stages, bone metastasis, } \\
\text { and tumor recurrence. The sensitivity } \\
\text { and specificity were } 94.6 \% \text { and } 92.8 \%\end{array}$ & 20,21 & \\
\hline miR-I9I & & $\begin{array}{l}\text { miR- } 191 \text { was the most stable gene, } \\
\text { showing the lowest degree of variation } \\
\text { and the highest stability value in PCa } \\
\text { urine samples }\end{array}$ & 23 & \\
\hline let-7 family & & $\begin{array}{l}\text { let-7 family was downregulated in } \mathrm{PCa} \\
\text { urine samples compared to the controls }\end{array}$ & 24 & \\
\hline \multicolumn{5}{|l|}{ Fusion gene } \\
\hline TMPRSS2-ERG & $\begin{array}{l}\text { TMPRSS2 (transmembrane } \\
\text { protease, serine 2), ERG (ETS } \\
\text { (erythroblast transformation- } \\
\text { specific)-related gene) }\end{array}$ & $\begin{array}{l}\text { A commercially available assay combining } \\
\text { serum PSA with urinary PCA } 3 \text { and } \\
\text { TMPRSS2-ERG provided a } 90 \% \text { specificity } \\
\text { and } 80 \% \text { sensitivity in diagnosing PCa }\end{array}$ & $9,27-29$ & \\
\hline \multicolumn{5}{|l|}{ Oncogene } \\
\hline AR-V7 & $\begin{array}{l}\text { Androgen receptor splice } \\
\text { variant-7 }\end{array}$ & $\begin{array}{l}\text { Patients with metastases but without } \\
\text { detectable AR-V7 RNA at baseline } \\
\text { had significantly longer OS and a trend } \\
\text { toward superior progression-free } \\
\text { survival }\end{array}$ & $30-33$ & \\
\hline AKRIC3 & $\begin{array}{l}\text { Aldo-keto reductase family I } \\
\text { member C3 }\end{array}$ & $\begin{array}{l}\text { AKRIC3 was associated with Gleason } \\
\text { score, PSA level, and the development } \\
\text { of CRPC }\end{array}$ & 34 & \\
\hline ANGPTL4 & Angiopoietin-like protein 4 & $\begin{array}{l}\text { Positive ANGPTL4 expression in } \\
\text { the resected PCa specimens was an } \\
\text { independent prognostic indicator of } \\
\text { biochemical recurrence }\end{array}$ & 35 & \\
\hline Cav-I & Caveolin-I & $\begin{array}{l}\text { Baseline Cav-I was a significant predictor } \\
\text { for risk of PCa }\end{array}$ & 36 & \\
\hline CCL2 & $\begin{array}{l}\text { Chemokine (C-C motif) } \\
\text { ligand } 2\end{array}$ & $\begin{array}{l}\text { Patients with } \mathrm{CCL} 2 \geq 320 \mathrm{pg} / \mathrm{mL} \text { had } \\
\text { worse OSI and PCa-specific survival than } \\
\text { those with } \mathrm{CCL} 2<320 \mathrm{pg} / \mathrm{mL}\end{array}$ & 37 & \\
\hline CLDN3 & Claudin 3 & $\begin{array}{l}\text { CLDN3 levels were higher in patients } \\
\text { with Gleason } \geq 8 \text { tumors compared } \\
\text { to patients with BPH and Gleason } \\
6-7 \text { tumors }\end{array}$ & 38 & \\
\hline
\end{tabular}

(Continued) 
Table I (Continued)

\begin{tabular}{|c|c|c|c|c|}
\hline Name & Full name & Predictive value & Ref & Application value \\
\hline CRP & C-reactive protein & $\begin{array}{l}\text { Patients with high serum CRP level } \\
(\geq 10 \mathrm{mg} / \mathrm{L}) \text { had significantly worse OS } \\
\text { than those patients with normal serum } \\
\text { CRP level }(<10 \mathrm{mg} / \mathrm{L})\end{array}$ & 39 & \\
\hline EGFR & $\begin{array}{l}\text { Epidermal growth factor } \\
\text { receptor }\end{array}$ & $\begin{array}{l}\text { Patients with EGFR-positive CTCs had a } \\
\text { shorter OS than patients with EGFR- } \\
\text { negative CTCs }\end{array}$ & 40 & \\
\hline EN2 & Engrailed-2 & $\begin{array}{l}\text { EN2 levels from the PCa and men with } \\
\text { BPH were related to the tumor stage, } \\
\text { Gleason score, and PSA }\end{array}$ & 41 & \\
\hline Fuc-Hpt & Fucosylated haptoglobin & $\begin{array}{l}\text { Serum Fuc-Hpt levels were significantly } \\
\text { associated with Gleason score and } \\
\text { biochemical recurrence, but not PSA } \\
\text { levels }\end{array}$ & 42 & \\
\hline GOAT & Ghrelin O-acyltransferase & $\begin{array}{l}\text { GOAT levels in PCa patients correlated } \\
\text { with aggressiveness and metabolic } \\
\text { conditions. GOAT might discriminate } \\
\text { PCa at the tissue/plasma/urine level with } \\
\text { high sensitivity/specificity, particularly in } \\
\text { nondiabetic individuals }\end{array}$ & 43 & \\
\hline HOXBI3 & Homeobox BI3 & $\begin{array}{l}\mathrm{HOXBI} 3 \text { is overexpressed during } \\
\text { malignant progression of the prostatic } \\
\text { tissue and suspected to contribute in the } \\
\text { pathogenesis of the prostate gland }\end{array}$ & 44 & \\
\hline MIC-I & $\begin{array}{l}\text { Macrophage inhibitory } \\
\text { cytokine I }\end{array}$ & $\begin{array}{l}\text { MIC-I concentration in serum } \\
\text { was elevated in PCa patients } \\
\text { compared to normal and biopsy-negative } \\
\text { individuals }\end{array}$ & 45 & \\
\hline$N F-\kappa B$ & Nuclear factor-kappa B p65 & $\begin{array}{l}\text { There was a significant association } \\
\text { between an increase in the nuclear } \\
\text { frequency of NF- } \mathrm{kB} \text { p } 65 \text { and Gleason } \\
\text { score, and development of metastases }\end{array}$ & 46 & \\
\hline NGF & Nerve growth factor & $\begin{array}{l}\text { Urinary NGF may be a biomarker for } \\
\text { higher-grade PCa }\end{array}$ & 47 & \\
\hline NPY & Neuropeptide-Y & $\begin{array}{l}\text { The combination of NPY and PSA had } \\
81.5 \% \text { sensitivity and } 82.2 \% \text { specificity for } \\
\text { PCa diagnosis }\end{array}$ & 48 & \\
\hline OLFM4 & Olfactomedin-4 & $\begin{array}{l}\text { Levels of circulating OLM4 were } \\
\text { significantly higher in patients with } \\
\text { cancers than in healthy subjects }\end{array}$ & 49 & \\
\hline OX & Oxytocin & $\begin{array}{l}\text { The levels of OX and its receptor in } \\
\text { serum were significantly increased in } \\
\text { PCa patients compared to the non- } \\
\text { carcinoma individuals }\end{array}$ & 50 & \\
\hline PPMID & $\begin{array}{l}\text { Protein phosphatase } \\
\text { magnesium-dependent I delta }\end{array}$ & $\begin{array}{l}\text { PPMID expression was positively } \\
\text { correlated with Gleason score, T stage, } \\
\text { and LN status. Kaplan-Meier curve } \\
\text { analysis showed that patients with } \\
\text { positive PPMID expression had shorter } \\
\text { RFS and OS }\end{array}$ & 51 & \\
\hline PSCA & Prostate stem cell antigen & PSCA was upregulated in PCa samples & 52 & \\
\hline PSGR & $\begin{array}{l}\text { Prostate-specific G-protein- } \\
\text { coupled receptor }\end{array}$ & $\begin{array}{l}\text { PSGR may be a potential PCa biomarker } \\
\text { and regulator of PCa invasion and } \\
\text { inflammation }\end{array}$ & 53 & \\
\hline
\end{tabular}


Table I (Continued)

\begin{tabular}{|c|c|c|c|c|}
\hline Name & Full name & Predictive value & Ref & Application value \\
\hline PTK7 & Protein tyrosine kinase 7 & $\begin{array}{l}\text { Elevated PTK7 expression was } \\
\text { significantly associated with LN } \\
\text { metastases, seminal vesicle invasion, } \\
\text { tumor stage, the higher preoperative PSA, } \\
\text { the higher Gleason score, angiolymphatic } \\
\text { invasion, and biochemical recurrence }\end{array}$ & 54 & \\
\hline PTX3 & Pentraxin 3 & $\begin{array}{l}\text { PTX3 serum levels may predict PCa } \\
\text { development }\end{array}$ & 55 & \\
\hline S4F & Semaphorin 4F & $\begin{array}{l}\text { S4F expression correlated with seminal } \\
\text { vesicle invasion, perineural invasion, and } \\
\text { biochemical recurrence }\end{array}$ & 56 & \\
\hline SPINKI & $\begin{array}{l}\text { Serine peptidase inhibitor, } \\
\text { Kazal type I }\end{array}$ & $\begin{array}{l}\text { SPINKI expression is dynamically } \\
\text { regulated with upregulation in primary } \\
\text { PCa and downregulation in LN } \\
\text { metastases }\end{array}$ & 57 & \\
\hline SPON2 & Spondin-2 & $\begin{array}{l}\text { Serum SPON2 levels were significantly } \\
\text { higher in patients with PCa than in } \\
\text { healthy individuals }\end{array}$ & 58 & \\
\hline TDRDI & Tudor domain containing I & $\begin{array}{l}\text { The expression of TDRDI was } \\
\text { significantly increased in ERG-positive } \\
\text { tumors }\end{array}$ & 59 & \\
\hline TFF3 & Trefoil factor 3 & $\begin{array}{l}\text { Sensitivity and specificity of combined } \\
\text { ERG and TFF3 expression in detecting } \\
\text { PCa were } 76 \% \text { and } 96 \% \text {, respectively }\end{array}$ & 60 & \\
\hline TKI & Thymidine kinase I & $\begin{array}{l}\text { Serum TKI levels were significantly } \\
\text { higher in PCa compared to blood donors }\end{array}$ & 61 & \\
\hline TRAF2 & $\begin{array}{l}\text { TNF (tumor necrosis factor) } \\
\text { receptor-associated factor } 2\end{array}$ & $\begin{array}{l}\text { High expression of TRAF2 was } \\
\text { significantly associated with PCa stage } \\
\text { and poorer RFS }\end{array}$ & 62 & \\
\hline TRPM4 & $\begin{array}{l}\text { Transient receptor potential } \\
\text { cation channel, subfamily M, } \\
\text { member } 4\end{array}$ & $\begin{array}{l}\text { Higher staining intensity had an increased } \\
\text { risk of biochemical recurrence compared } \\
\text { to patients with a lower staining intensity }\end{array}$ & 63 & \\
\hline XPO6 & Exportin 6 & $\begin{array}{l}\text { Relatively elevated expression of XPO6 } \\
\text { was significantly associated with poor } \\
\text { prognosis, in particular, with rapid } \\
\text { recurrence }\end{array}$ & 64 & \\
\hline \multicolumn{5}{|c|}{ Tumor suppressor gene } \\
\hline PTEN & $\begin{array}{l}\text { Phosphatase and tensin } \\
\text { homolog }\end{array}$ & $\begin{array}{l}\text { PTEN loss was associated with high } \\
\text { Gleason score in multiple-foci PCa cohort. } \\
\text { These samples with homozygous deletion } \\
\text { of PTEN were more likely to have } \\
\text { occurrence of biochemical recurrence }\end{array}$ & 9,65 & \\
\hline CLU & Clusterin & $\begin{array}{l}\text { Lowered serum CLU levels during } \\
\text { custirsen treatment were predictive of } \\
\text { longer survival in mCRPC }\end{array}$ & 66 & \\
\hline AZGPI & Zinc-alpha 2-glycoprotein & $\begin{array}{l}\text { Low/absent AZGPI expression was an } \\
\text { independent predictor of poor BRFS }\end{array}$ & 67 & $\begin{array}{l}\text { Low AZGPI expression provides } \\
\text { independent prognostic value in } \\
\text { PC (Phase III) }\end{array}$ \\
\hline PSFI & Partner of SLD5 I & $\begin{array}{l}\text { The PSFI expression correlated } \\
\text { significantly with PSA values at diagnosis, } \\
\text { with tumor grade, and with clinical } \\
\text { stage. Moreover, the PSFI expression } \\
\text { correlated significantly with OS and } \\
\text { progression-free survival }\end{array}$ & 68 & \\
\hline
\end{tabular}


Table I (Continued)

\begin{tabular}{|c|c|c|c|c|}
\hline Name & Full name & Predictive value & Ref & Application value \\
\hline CCLII & Eotaxin-I & $\begin{array}{l}\text { ROC analysis revealed that eotaxin-I } \\
\text { is a significant marker to distinguish } \\
\text { PCa from disease-free prostate. Urine } \\
\text { eotaxin-I was significantly decreased in } \\
\text { patients with PCa compared to cancer- } \\
\text { free individuals }\end{array}$ & 69 & \\
\hline SOX2 & $\begin{array}{l}\text { The SRY (sex-determining } \\
\text { region Y)-box } 2\end{array}$ & $\begin{array}{l}\text { SOX } 2 \text { mRNA expression in the primary } \\
\text { tumor was significantly associated with } \\
\text { LN metastasis }\end{array}$ & 70 & \\
\hline ARSB & $\begin{array}{l}\text { Arylsulfatase } \mathrm{B} \text {, } \\
\mathrm{N} \text {-acetylgalactosamine-4- } \\
\text { sulfatase }\end{array}$ & $\begin{array}{l}\text { In other paired normal and malignant } \\
\text { prostate tissues, ARSB activity was } \\
\text { significantly higher in the normal tissues }\end{array}$ & 71 & \\
\hline MAGI2 & $\begin{array}{l}\text { Membrane-associated } \\
\text { guanylate kinase inverted-2 }\end{array}$ & $\begin{array}{l}\text { The expression of MAGI2 mRNA was } \\
\text { significantly downregulated in PC } 3 \text {, } \\
\text { LNCaP, and DU- I } 45 \text { PCa cell lines, } \\
\text { and also in clinical tumor samples. } \\
\text { A significant correlation was observed } \\
\text { between MAGI2 and NKX } 3.1 \text { expression } \\
\text { in tumor samples. Furthermore, the } \\
\text { inclusion of MAGI2 in the gene panel } \\
\text { improved the accuracy for discrimination } \\
\text { between PCa and BPH samples with } \\
\text { the sensitivity and specificity of } 0.88 \text { and } \\
0.83 \text {, respectively }\end{array}$ & 72 & \\
\hline SLCI8A2 & $\begin{array}{l}\text { Solute carrier family } 18 \\
\text { (vesicular monoamine), } \\
\text { member } 2\end{array}$ & $\begin{array}{l}\text { SLCI8A2 transcript levels were reduced } \\
\text { in } P C \text { and had independent prognostic } \\
\text { value for } B C R \text { and OS }\end{array}$ & 73 & \\
\hline ADAMI9 & $\begin{array}{l}\text { A disintegrin and } \\
\text { metalloproteinase } 19\end{array}$ & $\begin{array}{l}\text { High levels of ADAMI } 9 \text { are positively } \\
\text { associated with lower stage and reduced } \\
\text { relapse of human PCa }\end{array}$ & 74 & \\
\hline EFEMPI & $\begin{array}{l}\text { Epidermal growth factor- } \\
\text { containing fibulin-like } \\
\text { extracellular matrix } \\
\text { protein I }\end{array}$ & $\begin{array}{l}\text { Serum and urine EFEMPI expression } \\
\text { was significantly downregulated } \\
\text { in patients with PCa compared to } \\
\text { that in the control groups. The low } \\
\text { expression of EFEMPI was obviously } \\
\text { affected by Gleason's score, serum PSA, } \\
\text { pathologic stage, and LN metastasis. } \\
\text { Moreover, there was a significant inverse } \\
\text { correlation between EFEMPI expression } \\
\text { and PSA levels. The ROC curve revealed } \\
\text { that EFEMPI distinguished PCa patients } \\
\text { from healthy controls }\end{array}$ & 75 & \\
\hline SFRPI & $\begin{array}{l}\text { Secreted frizzled-related } \\
\text { protein-I }\end{array}$ & $\begin{array}{l}\text { The expression of SFRPI was correlated } \\
\text { with the Gleason score, survival rate, } \\
\text { and response for endocrine therapy of } \\
\text { PCa. SFRPI may serve as an independent } \\
\text { predictive and prognostic factor for PCa }\end{array}$ & 76 & \\
\hline PBX3 & $\begin{array}{l}\text { Pre-B-cell leukemia } \\
\text { homeobox } 3\end{array}$ & $\begin{array}{l}\text { Competing risk regression analysis } \\
\text { revealed that high } \mathrm{PBX} 3 \text { expression was } \\
\text { associated with slower progression to } \\
\text { CRPC }\end{array}$ & 77 & \\
\hline \multicolumn{5}{|c|}{ Methylated biomarker } \\
\hline \multicolumn{5}{|l|}{ Hypermethylation } \\
\hline PITX2, PITX3 & $\begin{array}{l}\text { The paired-like homeodomain } \\
\text { transcription factors } 2 \text { and } 3\end{array}$ & $\begin{array}{l}\text { PITX2 methylation discriminated } \\
\text { between neoplastic and nonneoplastic }\end{array}$ & 78 & \\
\hline
\end{tabular}


Table I (Continued)

\begin{tabular}{|c|c|c|c|c|}
\hline Name & Full name & Predictive value & Ref & Application value \\
\hline & & $\begin{array}{l}\text { tissue in patients with PCa. PITX2 } \\
\text { methylation significantly correlated with } \\
\text { clinicopathologic parameters, and PITX2 } \\
\text { hypermethylation predicted an increased } \\
\text { risk of biochemical recurrence. PITX3 } \\
\text { showed a significant prognostic value for } \\
\text { BCR. PITX3 DNA methylation alone and } \\
\text { in combination with PITX } 2 \text { is a promising } \\
\text { biomarker for the risk stratification of } \\
\text { PCa patients }\end{array}$ & & \\
\hline PD-I, PD-LI & $\begin{array}{l}\text { Programmed death I, } \\
\text { programmed death ligand I }\end{array}$ & $\begin{array}{l}\text { Normal tissue showed significantly } \\
\text { lower levels of mPD-LI compared to } \\
\text { tumor tissue. High mPD-LI in PCa was } \\
\text { associated with BCR }\end{array}$ & 79 & \\
\hline CDOI & Cysteine dioxygenase I & $\begin{array}{l}\text { High } C D O I \text { methylation as continuous } \\
\text { variable was associated with } B C R\end{array}$ & 80 & \\
\hline GADD45a & $\begin{array}{l}\text { Growth arrest and DNA- } \\
\text { damage-inducible, alpha }\end{array}$ & $\begin{array}{l}\text { Serum GADD45a methylation was } \\
\text { significantly higher in PCa than in benign } \\
\text { patients }\end{array}$ & 81 & \\
\hline SLCI8A2 & $\begin{array}{l}\text { Solute carrier family } 18 \\
\text { (vesicular monoamine), } \\
\text { member } 2\end{array}$ & $\begin{array}{l}\text { SLCI8A2 promoter hypermethylation } \\
\text { was highly cancer-specific and associated } \\
\text { with BCR after RP }\end{array}$ & 73 & \\
\hline HISTIH4K & Histone cluster I, H4k & $\begin{array}{l}\text { Methylation of HISTIH4K showed } \\
\text { significant correlation with aging, } \\
\text { but with no other clinicopathologic } \\
\text { characteristics }\end{array}$ & 82 & \\
\hline cg05I63709 site & & $\begin{array}{l}\text { The ROC analysis showed a higher AUC } \\
\text { for cg05I63709 }(0.915) \text { than prostate- } \\
\text { specific antigen (PSA, 0.769) }\end{array}$ & 83 & \\
\hline \multicolumn{5}{|l|}{ Hypomethylation } \\
\hline TFF3 & Trefoil factor 3 & $\begin{array}{l}\text { Sensitivity and specificity of combined } \\
\text { ERG and TFF } 3 \text { expression in detecting } \\
\text { PCa were } 76 \% \text { and } 96 \% \text {, respectively }\end{array}$ & 84 & \\
\hline
\end{tabular}

Abbreviations: AUC, area under the curve; BRFS, biochemical recurrence-free survival; CRPC, castration-resistant prostate cancer; CTCs, circulating tumor cells; FDA, Food and Drug Administration; LN, lymph node; mCRPC, metastatic castrate-resistant prostate cancer; OS, overall survival; PCa, prostate cancer; ref, reference; RFS, recurrence-free survival; ROC, receiver operating characteristic; RP, radical prostatectomy.

were still in the laboratory research stage. We classified these molecules and looked forward for providing the researchers with a general overview of the PCa biomarkers.

\section{PSA}

PSA was the most widely used biomarker in clinical practice since the mid-80s. It was used as an adjunctive test to early screen $\mathrm{PCa}$, to assess patients' response to treatments, and to predict recurrence in the whole stage of PCa progression. In 1986, the Food and Drug Administration (FDA) approved that PSA was used for dynamic monitoring recurrence after initial treatment. ${ }^{5}$ Since then, the PCa cases in America doubled from 55/100,000 men to $110 / 100,000$. In 1994, FDA authorized that PSA was used in the clinic for early diagnosis of $\mathrm{PCa} .{ }^{6}$ However, until today we still do not know how many PSA screening has reduced PCa cases and costs. The European Randomized Study of Screening for Prostate Cancer has found that clinicians must screen 1,410 men and treat 48 potential patients to prevent one person from dying of PCa. ${ }^{5}$ In 2012, the US Preventative Services Task Force recommended that PSA testing was only used in high-risk populations. $^{\text {? }}$

Several derivatives of PSA, including serum free PSA and PSA velocity, and the isoforms of PSA, including p2PSA, have been considered as potential biomarkers to improve the diagnostic accuracy by combining with PSA. ${ }^{5}$ However, these auxiliary biomarkers are not PCa specific, which drastically reduces their application value. At present, PSA test is more commonly used as a screening method in clinical practice, and further diagnostic tests should be taken for 
patients with elevated PSA, whereas regular re-examination should be taken for the population with PSA in the gray zone (4-10 ng/mL).

\section{Long noncoding RNA}

A lot of long noncoding RNAs (lncRNA) were identified to be associated with tumor, which might play the important roles in carcinogenesis and PCa progression. LncRNAs not only promoted cancer cells proliferation, invasion, and metastasis, but also had the potential value to become biomarkers for predicting various tumors. Several kinds of PCa-related lncRNAs are summarized as follows.

Prostate cancer antigen 3 (PCA3) was overexpressed as a second-line biomarker in PCa tissues compared with control samples. Mechanistic studies illustrated that it might regulate androgen receptor (AR) signaling to improve $\mathrm{PCa}$ cell survival. In addition, PCA3 level was not increased in prostatic inflammatory or hyperplasia, and its level was not associated with prostatic volume. ${ }^{8}$ Moreover, PCA3 expression level was correlated with biopsy outcome and PCa progression (eg, tumor grade and Gleason score). ${ }^{8}$ In 2012, FDA approved that the PCA3 expression level was detected as a diagnostic test for PCa in the cases with a prior negative biopsy. ${ }^{9}$ Patients with PCA3 score $<25$ were 4.56 fold more likely to have a negative biopsy than men with its score $>25 .^{9}$ In 2017 , PCA3 performance was compared with the European Randomized Study of Screening for Prostate Cancer risk calculator model 3 in an opportunistic screening. ${ }^{10}$ Eight hundred thirty-eight men with a normal DRE result and $\mathrm{PSA} \geq 3 \mathrm{ng} / \mathrm{mL}$ had the PCA3 test done. In PCA3 positive $(n=301)$ and PCA3 negative $(n=256)$ groups, $40.9 \%$ and $14.7 \%$ PCa were identified, respectively $(P<0.001) .{ }^{10}$ The false-negative cases for high-grade PCa would be reduced by $37.1 \% .{ }^{10}$ Although the PCA3 screening might have potential as a second-line test used in men with high PSA levels, the prognostic value of PCA3 score remained controversial because the cutoff value was debated. Leyten et al found that sensitivity increased from 0.68 to 0.83 when the cutoff value reduced from 35 to 25 , while specificity decreased from 0.58 to $0.51 .{ }^{9}$

Besides, PCAT14 (prostate cancer-associated transcript 14) was a kind of PCa-related suppressive lncRNA, which was transcriptionally regulated by AR. PCAT14 was found to be downregulated in aggressive PCa, and the loss of PCAT14 might predict $\mathrm{PCa}$ recurrence based on the large-scale RNA-sequencing data. ${ }^{11}$ MALAT-1 (metastasis-associated lung adenocarcinoma transcript 1) had a higher area under the curve (AUC) compared to PSA level on the basis of a multicenter clinical trial to predict the risk of PCa before biopsy. The results showed that MALAT-1 might reduce $30.2 \%-46.5 \%$ of unnecessary biopsies with PSA $4-10 \mathrm{ng} / \mathrm{mL}$ using the cutoff value of $25 \% .{ }^{12}$ In addition, PCA18 (prostate cancer antigen 18) was also confirmed to be PCa-specific upregulated in $\mathrm{PCa}$ tissues compared with benign prostatic hyperplasia $(\mathrm{BPH})$ samples $(P<0.001) .{ }^{13}$ PVT1 (plasmacytoma variant translocation 1 ) exon 9 was associated with aggressive PCa. ${ }^{14}$ SChLAP1 (second chromosome locus associated with prostate-1) was upregulated in a subtype of PCa and associated with lethal PCa. The overexpression of SChLAP1 could independently predict biochemical recurrence of PCa after radical prostatectomy (RP). Knockdown of SChLAP1 induced apoptosis and inhibited cell invasion and metastasis. ${ }^{15,16}$

Among various lncRNAs, PCA3 has the most promising clinical application value and can be used as a second-line biomarker to predict the results of biopsy. Other lncRNAs also have great application prospects, and most of them are still in the research stage at present.

\section{MicroRNAs}

MicroRNA (miRNA) is a kind of small noncoding RNA with 20-24 nucleotides in length, which post-transcriptionally regulates target gene expressions by binding to the 3'-UTRs of complementary mRNAs. Deregulated miRNAs were reported to play dual roles in multiple cellular pathways in a variety of solid tumors.

A study found that the expression level of miR-34a was decreased in clinical PCa samples and was related with the progression and poor prognosis of $\mathrm{PCa}$, and miR-34a might regulate BCL-2, SNCA, and SCL7A5. ${ }^{17} \mathrm{miR}-1$ was significantly downregulated in recurrent $\mathrm{PCa}$ compared to nonrecurrent PCa samples $(P<0.001) .{ }^{18}$ There were 78 patients in the analysis, including 27 recurrent $\mathrm{PCa}$ and 51 nonrecurrent PCa. The Cox proportional hazards analysis revealed that miR-1 might be the independent prognostic factor for PCa recurrence (HR: 1.86, 95\% CI: 1.21-2.94; $P=0.011$ ). The AUC value of miR-1 was 0.885 , the sensitivity was 0.863 , and the specificity was $0.889(P<0.001) .{ }^{18}$ Another biochemical recurrence predictor, miR-129, was also downregulated in peripheral blood mononuclear cells (PBMC) isolated from $98 \mathrm{PCa}$ patients compared to 56 matched controls $(P<0.05) .{ }^{19}$ The expression level of miR-129 was significantly related with many $P C a$ clinical characteristics: PSA level $(P=0.002)$, tumor stage $(P=0.011)$, Gleason score $(P=0.005)$, lymph node metastasis $(P=0.002)$, and biochemical recurrence $(P=0.001)$, and so on. ${ }^{19}$ 
The expression levels of miR-21 were upregulated in PBMC from PCa patients compared to benign control group $(P<0.05) .{ }^{20}$ In the study, 92 PCa patients, $85 \mathrm{BPH}$ cases, and 97 healthy controls were involved. miR-21 expression level was significantly related with Gleason score, tumor stage, bone metastasis, and recurrence $(P<0.05)$. Receiver operating characteristic analysis uncovered that the AUC value of miR21 was 0.974 with $95 \%$ CI $0.956-0.993$. The sensitivity and specificity were $93.5 \%$ and $92.9 \%$, respectively. The results illustrated that the miR-21 expression level had the potential to be an independent biomarker for predicting the prognosis of PCa $(P<0.05) \cdot{ }^{20}$ Egidi et al also monitored the serum level of miR-21 in 38 patients with PCa before and after RP. MiR-21 was found to be significantly increased on the fifth day after surgery, and then gradually returned to the preoperative level. These findings suggested that miR-21 might be involved in postoperative inflammatory processes. ${ }^{21}$ Cochetti studied the serum level of miRNAs of PCa patients, and they found that seven miRNAs (let-7c, let-7e, let-7i, miR-26a-5p, miR-26b-5p, miR-18b-5p, and miR-25-3p) could distinguish PCa from BPH. ${ }^{22}$ In addition, Egidi ${ }^{23}$ and Guelfi ${ }^{24}$ detected miRNAs in the urine sediments, and found the potential application value of miR-191 $11^{23}$ and let-7 family ${ }^{24}$ as noninvasive biomarkers in the diagnosis of PCa.

Our group conducted a meta-analysis and a review on differentially expressed miRNAs in PCa. ${ }^{25,26}$ In the metaanalysis, we integrated the expression profile data of miRNAs and evaluated the value of miRNAs as biomarkers of $\mathrm{PCa}^{25}$ In the review, we also listed a variety of miRNAs that could identify $\mathrm{PCa}$ and $\mathrm{BPH} /$ normal. $^{26}$

\section{TMPRSS2-ERG}

In 2005, Tomlins et al first reported the gene fused between ERG (ETS (erythroblast transformation-specific)-related gene) and TMPRSS2 (transmembrane protease, serine 2) genes. ${ }^{27}$ TMPRSS2-ERG was the PCa-specific fusion gene, and there was ARE in the TMPRSS2 promoter, which might be activated by androgen, while the oncogene ERG was a kind of transcription factor as one member of ETS family. The fusion frequency of TMPRSS2-ERG was $~ 50 \%$ in Caucasian American cohorts, 31\% in African American cohorts, and $18.5 \%$ in Asian cohorts. The fusion gene could regulate proliferation, differentiation, cell cycle, and so on, and played an important role in the development of PCa. TMPRSS2-ERG fusion gene was thought to be the driving factor for PCa.

In 2011, Tomlins et al found that the expression level of TMPRSS2-ERG fusion in the urine samples of biopsy and prostatectomy was associated with $\mathrm{PCa}$ volume and Gleason score. But TMPRSS2-ERG had not been found to be associated with long-term patient outcomes: biochemical recurrence and $\mathrm{PCa}$-specific mortality. Using urinary TMPRSS2-ERG as a single marker, the test had low sensitivity but high specificity, which was very high up to $93.2 \% .{ }^{9}$ In the cohort studies, TMPRSS2-ERG fusion detection prior to biopsy was reported to avoid $35 \%-47 \%$ of biopsies, while to delay the diagnosis of high-grade PCa in only $1.0 \%-2.3 \%{ }^{9}$ Even so, TMPRSS2-ERG fusion-based screening was limited due to its low sensitivity. So, a method to improve the discriminatory ability of TMPRSS2-ERG fusion was proposed by combining with the other urinary markers: PSA or PCA3. ${ }^{28}$ Recently, a commercial kit might provide $90 \%$ specificity and $80 \%$ sensitivity for $\mathrm{PCa}$, combined detection of serum PSA, urinary PCA3, and TMPRSS2-ERG. ${ }^{28}$

In 2018, our group conducted a meta-analysis on the predictive potential of TMPRSS2-ERG fusion gene. The results showed that the expression level of TMPRSS2-ERG was associated with PCa tumor stage, Gleason score, and metastasis. But it was not related with biochemical recurrence, mortality, and tumor volume. At the same time, the data showed that deletion fusion was significantly correlated with the malignant degree of $\mathrm{PCa} .{ }^{29}$

\section{Oncogene}

In 2014, Antonarakis et al evaluated the expression level of androgen receptor splice variant-7 (AR-V7) in circulating tumor cells (CTCs) from metastatic castrate-resistant prostate cancer (mCRPC) patients treated by enzalutamide or abiraterone. The results demonstrated that the AR-V7 expression was associated with $\mathrm{PCa}$ shorter survival. ${ }^{30} \mathrm{In}$ 2016, Scher et al also verified that patients with AR-V7-positive CTCs had shorter radiographic progression-free survival and shorter overall survival (OS) than those with AR-V7-negative in 161 progressive mCRPC patients (HR: $0.24,95 \%$ CI: $0.10-0.57 ; P=0.035){ }^{31}$ In 2017 , Saylor et al ${ }^{32}$ got the similar conclusion. Subsequently, Conteduca et al $^{33}$ conducted the meta-analysis on the association between AR-V7 with OS or PFS in two patient cohorts: primary cohort (73 chemotherapy-naïve, 98 post-docetaxel CRPC patients) and secondary cohort (94 chemotherapy- naïve patients). The meta-analysis results suggested that AR was associated with poorer OS (primary cohort: HR: $3.98,95 \%$ CI: $1.74-9.10 ; P<0.001$ and secondary cohort: HR: 11.08 , 95\% CI: $2.16-56.95 ; P=0.004$ ) and worse PFS (primary cohort: HR: $2.18,95 \%$ CI: $1.08-4.39 ; P=0.03$ and secondary cohort: HR: $4.33,95 \%$ CI: $1.94-9.68 ; P<0.001) .{ }^{33}$ All of the 
above-mentioned studies supported that AR-V7 might be a predictive biomarker for PCa outcomes.

Besides, many proto-oncogenes are listed in Table 1. And some predictive cases of combined use of multiple oncogenes were mentioned in the discussion section. However, the oncogenes to predict and diagnose PCa have not been used in clinical practice, and a large number of experiments are still needed.

\section{Tumor suppressor gene}

Phosphatase and tensin homolog (PTEN) is a tumor suppressor gene to regulate proliferation, cell cycle, and apoptosis by a lot of downstream target genes. Among them, phosphatidylinositol-3,4,5 phosphate (PIP3) is dephosphorylated by PTEN to become phosphatidylinositol-4,5 phosphate (PIP2), then the membrane lipid is activated and released Akt kinase. In 2015, Shah et al reported that PTEN loss was associated with high Gleason score $(P<0.01)$ in 194 multiple-foci PCa cohort. ${ }^{65}$ PTEN loss was found in 36\% (69) of patients. Moreover, 39\% of tumor samples with hemizygous PTEN deletion was reported by Yoshimoto, while homozygous deletion was found in 5\% of cases, and these samples with homozygous deletion were more likely to occur biochemical recurrence $(P=0.005){ }^{9}$

Clusterin (CLU) is a stress-induced cytoprotective chaperone, associated with tumor stage, metastasis, and treatment resistance for some cancers. In a Phase II clinical study on custirsen, a CLU antisense oligonucleotide, custirsen as a second-line drug was evaluated in patients with mCRPC. The results showed that the lower serum CLU level indicated the longer survival period in mCRPC patients during the treatment with custirsen. ${ }^{66}$ Moreover, in a Phase III trial, the low expression of AZGP1 (zinc-alpha 2-glycoprotein) might independently predict the shorter recurrence-free survival (HR, 1.9; 95\% CI: $1.1-3.3 ; P=0.02){ }^{67}$

PSF1 (Partner of SLD51) is a kind of DNA replication factor, which was verified that its transcriptional activity was related with Gleason score $(P<0.0001)$, PSA level $(P=0.0028)$, and tumor stage $(P=0.0005)$ in 120 PCa biopsy samples. Noteworthily, PSF1 was also associated with OS (HR: 5.5, 95\% CI: 2.17-15.8; $P=0.003$ ) and prognosis (HR: 3.7, 95\% CI: $1.28-13.43 ; P=0.0143)$ in 99 PCa patients. ${ }^{68}$ Eotaxin-1 (CCL11) is an immunomodulatory chemokine attracting eosinophils. In the study using serum from 140 patients with elevated PSA levels and 20 controls, it was found that serum CCL11 levels were decreased in PCa group compared to the control $(P=0.006)$, and eotaxin-1 might be a potential biomarker to distinguish $\mathrm{PCa}$ patients from benign prostate cases. ${ }^{69}$
In addition, other tumor suppressors were also confirmed to be downregulated in PCa compared to that in the healthy controls, including SOX2 (the SRY (sex-determining region Y)-box 2), ${ }^{70}$ ARSB (arylsulfatase B, N-acetylgalactosamine4-sulfatase) $(P<0.0001),{ }^{71}$ MAGI2 (membrane-associated guanylate kinase inverted-2) $(P=0.002),{ }^{72}$ SLC18A2 (solute carrier family 18 [vesicular monoamine], member 2) $(P<0.05),{ }^{73}$ ADAM19 (a disintegrin and metalloproteinase 19) $(P<0.05),{ }^{74}$ EFEMP1 (epidermal growth factor-containing fibulin-like extracellular matrix protein 1) $(P<0.05),{ }^{75}$ and SFRP1 (secreted frizzled-related protein-1) $(P=0.016) .{ }^{76}$ High PBX3 (pre-B-cell leukemia homeobox 3) expression was related with slower progression to CRPC (HR: 0.18, 95\% CI: 0.081-0.42; $P<0.001){ }^{77}$

PCa-related tumor suppressor genes are the same as oncogenes. On the one hand, their application value remains to be proved; on the other hand, they are more suitable for the combined use of multiple genes to score $\mathrm{PCa}$, so as to guide the clinical evaluation of the malignant degree and prognosis of $\mathrm{PCa}$.

\section{Methylated biomarker}

Currently, there are more and more studies that have reported the association between DNA methylation and the carcinogenesis and progression of PCa. Aberrant DNA methylation of cancer-related genes plays an important role to regulate various kinds of signal pathways. So hypermethylated genes seem to be potential biomarkers, which may help to distinguish aggressive $\mathrm{PCa}$ from $\mathrm{PCa}$ without obvious clinical symptoms.

ConfirmMDx is a kind of assay analyzing DNA methylation patterns of several key tumor suppressors, such as glutathione S-transferase pi 1 (GSTP1), Ras association (RalGDS/AF-6) domain family member 1 (RASSF1), and adenomatosis polyposis coli (APC). ${ }^{9}$ Among them, GSTP1 participates in detoxification, RASSF1 regulates cell cycle, and APC participates in apoptosis, cell migration, and adhesion. ${ }^{9}$ In addition, hypermethylation of PITX2 (the paired-like homeodomain transcription factor 2) and PITX3 (paired-like homeodomain transcription factor 3) were also powerful predictors for PCa patients, which might discriminate neoplastic and nonneoplastic prostate tissues $(P<0.001)$, and predict the risk of biochemical recurrence (HR: 2.56, 95\% CI: $1.44-4.54 ; P=0.001) .{ }^{78}$ Gevensleben et al evaluated the potential of hypermethylated PD-1 (programmed death 1) and PD-L1 (programmed death ligand 1) as biomarkers in PCa. First, DNA methylation of PD-1 and PD-L1 was of lower level in normal tissue compared to tumor tissue. Secondly, 
hypermethylated PD-L1 was related with biochemical recurrence (HR: $1.24,95 \%$ CI: $1.08-1.43 ; P=0.002$ ) in PCa. These results indicated that $\mathrm{PD}-\mathrm{L} 1$ methylation might be a prognostic biomarker for the risk assessment of PCa patients. ${ }^{79}$ Furthermore, the promoter methylation of CDO1 (cysteine dioxygenase 1), ${ }^{80}$ GADD45a (growth arrest and DNA-damage-inducible, alpha), ${ }^{81}$ SLC18A2, ${ }^{73}$ and HIST1H4K (histone cluster $1, \mathrm{H} 4 \mathrm{k})^{82}$ was also evaluated as prognostic biomarkers for biochemical recurrence of PCa patients after RP. In 2015 , Yao et al found six aberrant methylation sites located on the Y-chromosome in PCa tissues. Among them, the methylated site (cg05163709) could become a potential diagnostic biomarker with a high AUC (0.915). ${ }^{83}$

Except for hypermethylation, hypomethylation of trefoil factor 3 (TFF3) promoter was studied as a PCa biomarker in 292 RP patients and another 498 PCa cases by quantitative methylation-specific PCR and DNA methylation arrays and RNA sequencing. ${ }^{84}$ These results demonstrated that the hypomethylation of TFF3 promoter and its high expression were significant in $\mathrm{PCa}$ tissues compared to benign prostatic samples $(P<0.001)$. Moreover, the expression level of TFF3 was associated with high ERG $(P<0.001)$, high Gleason score $(P<0.001)$, tumor stage $(P<0.001)$, and PSA recurrence after RP $(P=0.013){ }^{84}$

Both hypermethylation and hypomethylation belong to epigenetics. They are mainly used to predict the possibility of biochemical recurrence of $\mathrm{PCa}$ patients, and to assess the susceptibility to PCa.

\section{Discussion}

We had summarized a variety of biomarkers for PCa. Except for the molecules mentioned above, aberrant lipid metabolism markers, involving cholesteryl esters, ${ }^{85}$ sterol regulatory element-binding protein-1, and fatty acid synthase, ${ }^{86}$ were associated with PCa stage and Gleason score, and might distinguish PCa from benign prostate tissues. The circulating autoantibodies against tumor-associated antigens could also assist serum PSA screening to discriminate PCa from benign patients. ${ }^{87,88}$ Single-nucleotide variant (SNV) ${ }^{14}$ or copy number variations $(\mathrm{CNV})^{89}$ often led to the heterogeneity of PCa, which could be used as the characteristic of some subtype of PCa. Besides, thiosulfate ${ }^{90}$ and miR-205 $5^{91}$ were reported not to be suitable as biomarkers for PCa.

In Alford's review, 12 commercially available biomarker assays were summarized, which provided urologists multifaceted information about PCa outcomes and therapeutic effects. ${ }^{9}$ For example, SelectMDx might be used in post-DRE urine samples, involving distal-less homeobox
1, HOXC6 (homeobox C6), serum PSA level, PSA density, DRE score, age at diagnosis, and family history. ${ }^{9}$ The oncotype DX assay measured the transcriptional levels of 17 genes by the quantitative reverse transcriptase-polymerase chain reaction, including 5 reference genes (ARF, ATP5E, CLTC, GPS1, PGK1) and 12 genes involved in the androgen pathway, cellular organization, proliferation, and stromal response. ${ }^{9}$ Summarizing the experience of these commercially valuable kits, we found that PCa scoring combined with multiple biomarkers might be an effective method for future clinical use.

Another concern for researchers is the origin of biomarkers. Exosomes, CTCs, and cell-free-circulating-tumor DNA collected from $\mathrm{PCa}$ patients might be the promising source of biomarkers for evaluating PCa diagnosis and prognosis, and they could be candidate markers by themselves, such as CTC count and cell-free DNA integrity. Another advantage for these body fluid specimens is convenience and noninvasive. Among them, exosomes are vesicles that carry proteins, DNA, lipids, and metabolites, and 30-150 $\mathrm{nm}$ in diameter, which can come from either blood or body fluids, such as patient's urine.

In summary, a combination of multiple biomarkers should be a feasible and accurate way to assess PCa risk. In addition, a series of marker tests can provide more powerful guidance for medical decision based on the patients' different clinical and pathologic stages. Of course, a lot of laboratory and clinical experiments are still needed to achieve the goal.

\section{Conclusion}

In the review, we summarized the molecules found in recent several years, which had the potential to become biomarkers for the diagnosis and prognosis of PCa. Furthermore, we divided them into several categories, such as noncoding RNA, fusion gene, proto-oncogene, tumor suppressor gene, and gene methylation. Some of them had been applied in clinical practice, or were being developed to be used in the commercial reagent kits. However, most of the molecules were still in the laboratory research stage. More laboratory tests and clinical trials were needed.

\section{Acknowledgments}

This work was supported by Zhejiang Provincial Science Technology Program of China (2013C33101), Zhejiang Medical Platform Program (2015RCA023), and Shaoxing Municipal Health and Family Planning Science and Technology Innovation Project (2017CX004). 


\section{Disclosure}

The authors report no conflicts of interest in this work.

\section{References}

1. Torre LA, Bray F, Siegel RL, et al. Global cancer statistics, 2012. CA Cancer J Clin. 2015;65(2):87-108.

2. Ryerson AB, Eheman CR, Altekruse SF, et al. Annual report to the nation on the status of cancer, 1975-2012, featuring the increasing incidence of liver cancer. Cancer. 2016;122(9):1312-1337.

3. Siegel RL, Miller KD, Jemal A. Cancer statistics, 2017. CA Cancer J Clin. 2017;67(1):7-30.

4. Wolf AM, Wender RC, Etzioni RB, et al; American Cancer Society Prostate Cancer Advisory Committee. American Cancer Society guideline for the early detection of prostate cancer: update 2010. CA Cancer J Clin. 2010;60(2):70-98.

5. Andriole GL, Crawford ED, Grubb RL, et al. Mortality results from a randomized prostate-cancer screening trial. $N$ Engl J Med. 2009; 360(13):1310-1319.

6. Dellavedova T. Prostatic specific antigen. From its early days until becoming a prostate cancer biomarker. Arch Esp Urol. 2016;69(1): 19-23.

7. Pérot P, Cheynet V, Decaussin-Petrucci M, et al. Microarray-based identification of individual HERV loci expression: application to biomarker discovery in prostate cancer. J Vis Exp. 2013;81:e50713.

8. Rubio-Briones J, Casanova J, Martínez F, et al. PCA3 as a second-line biomarker in a prospective controlled randomized opportunistic prostate cancer screening programme. Actas Urol Esp. 2017;41(5):300-308.

9. Alford AV, Brito JM, Yadav KK, et al. The use of biomarkers in prostate cancer screening and treatment. Rev Urol. 2017;19(4):221-234.

10. Rubio-Briones J, Casanova J, Martínez F, et al. PCA3 as a second-line biomarker in a prospective controlled randomized opportunistic prostate cancer screening programme. Actas Urol Esp. 2017;41(5):300-308.

11. Shukla S, Zhang X, Niknafs YS, et al. Identification and validation of PCAT14 as prognostic biomarker in prostate cancer. Neoplasia. 2016; 18(8):489-499.

12. Wang F, Ren S, Chen R, et al. Development and prospective multicenter evaluation of the long noncoding RNA MALAT-1 as a diagnostic urinary biomarker for prostate cancer. Oncotarget. 2014;5(22): 11091-11102

13. Crea F, Watahiki A, Quagliata L, et al. Identification of a long noncoding RNA as a novel biomarker and potential therapeutic target for metastatic prostate cancer. Oncotarget. 2014;5(3):764-774.

14. Ilboudo A, Chouhan J, McNeil B, Osborne J, Ogunwobi O. PVT1 exon 9: a potential biomarker of aggressive prostate cancer? Int J Environ Res Public Health. 2015;13(1):12.

15. Li Y, Luo H, Xiao N, Duan J, Wang Z, Wang S. Long noncoding RNA SChLAP1 accelerates the proliferation and metastasis of prostate cancer via targeting miR-198 and promoting the MAPK1 pathway. Oncol Res. 2018;26(1):131-143.

16. Mehra R, Udager AM, Ahearn TU, et al. Overexpression of the long non-coding RNA SChLAP1 independently predicts lethal prostate cancer. Eur Urol. 2016;70(4):549-552.

17. Corcoran C, Rani S, O'Driscoll L. miR-34a is an intracellular and exosomal predictive biomarker for response to docetaxel with clinical relevance to prostate cancer progression. Prostate. 2014;74(13):1320-1334.

18. Wei W, Leng J, Shao H, Wang W. MiR-1, a potential predictive biomarker for recurrence in prostate cancer after radical prostatectomy. Am J Med Sci. 2017;353(4):315-319.

19. Xu S, Yi XM, Zhou WQ, et al. Downregulation of miR-129 in peripheral blood mononuclear cells is a diagnostic and prognostic biomarker in prostate cancer. Int J Clin Exp Pathol. 2015;8(11):14335-14344.

20. Yang B, Liu Z, Ning H, et al. MicroRNA-21 in peripheral blood mononuclear cells as a novel biomarker in the diagnosis and prognosis of prostate cancer. Cancer Biomark. 2016;17(2):223-230.

21. Egidi MG, Cochetti G, Serva MR, et al. Circulating microRNAs and kallikreins before and after radical prostatectomy: are they really prostate cancer markers? Biomed Res Int. 2013;2013:241780.
22. Cochetti G, Poli G, Guelfi G, et al. Different levels of serum microRNAs in prostate cancer and benign prostatic hyperplasia: evaluation of potential diagnostic and prognostic role. Onco Targets Ther. 2016;9: 7545-7553.

23. Egidi MG, Cochetti G, Guelfi G, et al. Stability assessment of candidate reference genes in urine sediment of prostate cancer patients for miRNA applications. Dis Markers. 2015;2015:973597.

24. Guelfi G, Cochetti G, Stefanetti V, et al. Next generation sequencing of urine exfoliated cells: an approach of prostate cancer microRNAs research. Sci Rep. 2018;8(1):7111.

25. Song CJ, Chen H, Chen LZ, et al. The potential of microRNAs as human prostate Cancer biomarkers: a meta-analysis of related studies. J Cell Biochem. 2018;119(3):2763-2786.

26. Song $\mathrm{C}$, Chen H, Chunyu S. Expression profiles and mechanisms of microRNAs in prostate cancer. Biomarkers J. 2018;4(S1):13.

27. Tomlins SA, Rhodes DR, Perner S, et al. Recurrent fusion of TMPRSS2 and Ets transcription factor genes in prostate cancer. Science. 2005;310(5748):644-648

28. Sanguedolce F, Cormio A, Brunelli M, et al. Urine TMPRSS2: ERG fusion transcript as a biomarker for prostate cancer: literature review. Clin Genitourin Cancer. 2016;14(2):117-121.

29. Song C, Chen H. Predictive significance of TMRPSS2-ERG fusion in prostate cancer: a meta-analysis. Cancer Cell Int. 2018;18:177.

30. Antonarakis ES, Nakazawa M, Luo J. Resistance to androgen-pathway drugs in prostate cancer. N Engl J Med. 2014;371(23):2234.

31. Scher HI, Lu D, Schreiber NA, et al. Association of AR-V7 on circulating tumor cells as a treatment-specific biomarker with outcomes and survival in castration-resistant prostate cancer. JAMA Oncol. 2016; 2(11): 1441-1449.

32. Saylor PJ, Lee RJ, Arora KS, et al. Branched chain RNA in situ hybridization for androgen receptor splice variant AR-V7 as a prognostic biomarker for metastatic castration-sensitive prostate cancer. Clin Cancer Res. 2017;23(2):363-369.

33. Conteduca V, Wetterskog D, Sharabiani MTA, et al. Androgen receptor gene status in plasma DNA associates with worse outcome on enzalutamide or abiraterone for castration-resistant prostate cancer: a multi-institution correlative biomarker study. Ann Oncol. 2017;28(7): $1508-1516$.

34. Tian $\mathrm{Y}$, Zhao L, Zhang H, et al. AKR1C3 overexpression may serve as a promising biomarker for prostate cancer progression. Diagn Pathol. 2014;9:42.

35. Hata S, Nomura T, Iwasaki K, et al. Hypoxia-induced angiopoietin-like protein 4 as a clinical biomarker and treatment target for human prostate cancer. Oncol Rep. 2017;38(1):120-128.

36. Basourakos SP, Davis JW, Chapin BF, et al. Baseline and longitudinal plasma caveolin-1 level as a biomarker in active surveillance for earlystage prostate cancer. BJU Int. 2018;121(1):69-76.

37. Izumi K, Mizokami A, Lin HP, et al. Serum chemokine (CC motif) ligand 2 level as a diagnostic, predictive, and prognostic biomarker for prostate cancer. Oncotarget. 2016;7(7):8389-8398.

38. Worst TS, von Hardenberg J, Gross JC, et al. Database-augmented mass spectrometry analysis of exosomes identifies claudin 3 as a putative prostate cancer biomarker. Mol Cell Proteomics. 2017;16(6): 998-1008.

39. $\mathrm{Xu} \mathrm{L}$, Zhao Q, Huang S, et al. Serum C-reactive protein acted as a prognostic biomarker for overall survival in metastatic prostate cancer patients. Tumour Biol. 2015;36(2):669-673.

40. Okegawa T, Itaya N, Hara H, Tambo M, Nutahara K. Epidermal growth factor receptor status in circulating tumor cells as a predictive biomarker of sensitivity in castration-resistant prostate cancer patients treated with docetaxel chemotherapy. Int J Mol Sci. 2016;17(12):2008.

41. Marszałł MP, Sroka W, Adamowski M, et al. Engrailed-2 protein as a potential urinary prostate cancer biomarker: a comparison study before and after digital rectal examination. Eur J Cancer Prev. 2015;24(1): 51-56.

42. Fujita K, Shimomura M, Uemura M, et al. Serum fucosylated haptoglobin as a novel prognostic biomarker predicting high-Gleason prostate cancer. Prostate. 2014;74(10):1052-1058. 
43. Hormaechea-Agulla D, Gómez-Gómez E, Ibáñez-Costa A, et al. Ghrelin O-acyltransferase (GOAT) enzyme is overexpressed in prostate cancer, and its levels are associated with patient's metabolic status: potential value as a non-invasive biomarker. Cancer Lett. 2016;383(1): 125-134.

44. Ouhtit A, Kindi M, Kumar PR, et al. HOXB13, a potential prognostic biomarker for prostate cancer. Front Biosci. 2016;8:40-45.

45. Li J, Veltri RW, Yuan Z, Christudass CS, Mandecki W. Macrophage inhibitory cytokine 1 biomarker serum immunoassay in combination with PSA is a more specific diagnostic tool for detection of prostate cancer. PLoS One. 2015;10(4):e0122249.

46. Gannon PO, Lessard L, Stevens LM, et al. Large-scale independent validation of the nuclear factor-kappa B p65 prognostic biomarker in prostate cancer. Eur J Cancer. 2013;49(10):2441-2448.

47. Liss MA, Gordon A, Morales B, et al. Urinary nerve growth factor as an oncologic biomarker for prostate cancer aggressiveness. Urol Oncol. 2014;32(5):714-719

48. Ueda K, Tatsuguchi A, Saichi N, et al. Plasma low-molecularweight proteome profiling identified neuropeptide-Y as a prostate cancer biomarker polypeptide. J Proteome Res. 2013;12(10): 4497-4506.

49. Guette C, Valo I, Vétillard A, Coqueret O. Olfactomedin-4 is a candidate biomarker of solid gastric, colorectal, pancreatic, head and neck, and prostate cancers. Proteomics Clin Appl. 2015;9(1-2):58-63.

50. $\mathrm{Xu} \mathrm{H}, \mathrm{Fu} \mathrm{S}, \mathrm{Chen} \mathrm{Q}$, et al. The function of oxytocin: a potential biomarker for prostate cancer diagnosis and promoter of prostate cancer. Oncotarget. 2017;8(19):31215-31226.

51. Jiao L, Shen D, Liu G, et al. PPM1D as a novel biomarker for prostate cancer after radical prostatectomy. Anticancer Res. 2014;34(6): 2919-2925.

52. Bargão Santos P, Patel HR. Prostate stem cell antigen - novel biomarker and therapeutic target? Expert Rev Anticancer Ther. 2014;14(1) $5-7$.

53. Rodriguez M, Siwko S, Liu M. Prostate-specific G-protein coupled receptor, an emerging biomarker regulating inflammation and prostate cancer invasion. Curr Mol Med. 2016;16(6):526-532.

54. Zhang H, Wang A, Qi S, et al. Protein tyrosine kinase 7 (PTK7) as a predictor of lymph node metastases and a novel prognostic biomarker in patients with prostate cancer. Int J Mol Sci. 2014;15(7): 11665-11677.

55. Stallone G, Cormio L, Netti GS, et al. Pentraxin 3: a novel biomarker for predicting progression from prostatic inflammation to prostate cancer Cancer Res. 2014;74(16):4230-4238.

56. Ding Y, He D, Florentin D, et al. Semaphorin $4 \mathrm{~F}$ as a critical regulator of neuroepithelial interactions and a biomarker of aggressive prostate cancer. Clin Cancer Res. 2013;19(22):6101-6111.

57. Huang K-C, Bégin LR, Palanisamy N, Donnelly B, Bismar TA. SPINK1 expression in relation to PTEN and ERG in matched primary and lymph node metastatic prostate cancer: implications for biomarker development. Urol Oncol. 2016;34(5):235.e1-236.e10.

58. Lucarelli G, Rutigliano M, Bettocchi C, et al. Spondin-2, a secreted extracellular matrix protein, is a novel diagnostic biomarker for prostate cancer. J Urol. 2013;190(6):2271-2277.

59. Xiao L, Lanz RB, Frolov A, et al. The germ cell gene TDRD1 as an ERG target gene and a novel prostate cancer biomarker. Prostate. 2016; 76(14):1271-1284.

60. Park K, Chiu YL, Rubin MA, Demichelis F, Mosquera JM. V-ets erythroblastosis virus E26 oncogene homolog (avian)/Trefoil factor 3/ high-molecular-weight cytokeratin triple immunostain: a novel tissuebased biomarker in prostate cancer with potential clinical application Hum Pathol. 2013;44(10):2282-2292.

61. Jagarlamudi KK, Hansson LO, Eriksson S. Breast and prostate cancer patients differ significantly in their serum thymidine kinase 1 (TK1) specific activities compared with those hematological malignancies and blood donors: implications of using serum TK1 as a biomarker. BMC Cancer. 2015;15:66.

62. Wei B, Liang $\mathrm{J}, \mathrm{Hu} \mathrm{J}$, et al. TRAF2 is a valuable prognostic biomarker in patients with prostate cancer. Med Sci Monit. 2017;23:4192-4204.
63. Berg KD, Soldini D, Jung M, et al. TRPM4 protein expression in prostate cancer: a novel tissue biomarker associated with risk of biochemical recurrence following radical prostatectomy. Virchows Arch. 2016;468(3):345-355.

64. Hao J, Chiang YT, Gout PW, et al. Elevated XPO6 expression as a potential prognostic biomarker for prostate cancer recurrence. Front Biosci. 2016;8:44-55.

65. Shah RB, Bentley J, Jeffery Z, Demarzo AM. Heterogeneity of PTEN and ERG expression in prostate cancer on core needle biopsies: implications for cancer risk stratification and biomarker sampling. Hum Pathol. 2015;46(5):698-706.

66. Blumenstein B, Saad F, Hotte S, et al. Reduction in serum clusterin is a potential therapeutic biomarker in patients with castration-resistant prostate cancer treated with custirsen. Cancer Med. 2013;2(4): 468-477.

67. Zhang AY, Grogan JS, Mahon KL, et al. A prospective multicentre phase III validation study of AZGP1 as a biomarker in localized prostate cancer. Ann Oncol. 2017;28(8):1903-1909.

68. Tahara H, Naito H, Kise K, et al. Evaluation of PSF1 as a prognostic biomarker for prostate cancer. Prostate Cancer Prostatic Dis. 2015; 18(1):56-62.

69. Heidegger I, Höfer J, Luger M, et al. Is Eotaxin-1 a serum and urinary biomarker for prostate cancer detection and recurrence? Prostate. 2015; 75(16):1904-1909.

70. Russo MV, Esposito S, Tupone MG, et al. Sox2 boosts major tumor progression genes in prostate cancer and is a functional biomarker of lymph node metastasis. Oncotarget. 2016;7(11):12372-12385.

71. Feferman L, Bhattacharyya S, Deaton R, et al. Arylsulfatase B (N-acetylgalactosamine-4-sulfatase): potential role as a biomarker in prostate cancer. Prostate Cancer Prostatic Dis. 2013;16(3): 277-284.

72. Mahdian R, Nodouzi V, Asgari M, et al. Expression profile of MAGI2 gene as a novel biomarker in combination with major deregulated genes in prostate cancer. Mol Biol Rep. 2014;41(9):6125-6131.

73. Haldrup C, Lynnerup AS, Storebjerg TM, et al. Large-scale evaluation of SLC18A2 in prostate cancer reveals diagnostic and prognostic biomarker potential at three molecular levels. Mol Oncol. 2016;10(6): 825-837.

74. Hoyne G, Rudnicka C, Sang QX, et al. Genetic and cellular studies highlight that a disintegrin and metalloproteinase 19 is a protective biomarker in human prostate cancer. BMC Cancer. 2016;16:151.

75. Shen H, Zhang L, Zhou J, et al. Epidermal growth factor-containing fibulin-like extracellular matrix protein 1 (EFEMP1) acts as a potential diagnostic biomarker for prostate cancer. Med Sci Monit. 2017;23: 216-222.

76. Zheng L, Sun D, Fan W, et al. Diagnostic value of SFRP1 as a favorable predictive and prognostic biomarker in patients with prostate cancer. PLoS One. 2015;10(2):e0118276.

77. Ramberg H, Grytli HH, Nygård S, et al. PBX3 is a putative biomarker of aggressive prostate cancer. Int J Cancer. 2016;139(8):1810-1820.

78. Uhl B, Gevensleben H, Tolkach Y, et al. PITX2 DNA methylation as biomarker for individualized risk assessment of prostate cancer in core biopsies. J Mol Diagn. 2017;19(1):107-114.

79. Gevensleben H, Holmes EE, Goltz D, et al. PD-L1 promoter methylation is a prognostic biomarker for biochemical recurrence-free survival in prostate cancer patients following radical prostatectomy. Oncotarget. 2016;7(48):79943-79955.

80. Meller S, Zipfel L, Gevensleben H, et al. CDO1 promoter methylation is associated with gene silencing and is a prognostic biomarker for biochemical recurrence-free survival in prostate cancer patients. Epigenetics. 2016;11(12):871-880.

81. Reis IM, Ramachandran K, Speer C, Gordian E, Singal R. Serum Gadd45a methylation is a useful biomarker to distinguish benign vs malignant prostate disease. Br J Cancer. 2015;113(3):460-468.

82. Kachakova D, Mitkova A, Popov E, et al. Evaluation of the clinical value of the newly identified urine biomarker HIST1H4K for diagnosis and prognosis of prostate cancer in Bulgarian patients. J Buon. 2013; 18(3):660-668. 
83. Yao L, Ren S, Zhang M, et al. Identification of specific DNA methylation sites on the Y-chromosome as biomarker in prostate cancer. Oncotarget. 2015;6(38):40611-40621.

84. Nørgaard M, Haldrup C, Storebjerg T, et al. Comprehensive evaluation of TFF3 promoter hypomethylation and molecular biomarker potential for prostate cancer diagnosis and prognosis. Int J Mol Sci. 2017;18(9):2017.

85. Li J, Ren S, Piao HL, et al. Integration of lipidomics and transcriptomics unravels aberrant lipid metabolism and defines cholesteryl oleate as potential biomarker of prostate cancer. Sci Rep. 2016;6:20984.

86. O’Malley J, Kumar R, Kuzmin AN, et al. Lipid quantification by Raman microspectroscopy as a potential biomarker in prostate cancer. Cancer Lett. 2017;397:52-60.

87. Dai L, Li J, Xing M, et al. Using serological proteome analysis to identify serum anti-nucleophosmin 1 autoantibody as a potential biomarker in European-American and African-American patients with prostate cancer. Prostate. 2016;76(15):1375-1386.
88. Li J, Dai L, Lei N, et al. Evaluation and characterization of anti-RalA autoantibody as a potential serum biomarker in human prostate cancer. Oncotarget. 2016;7(28):43546-43556.

89. Schütz E, Akbari MR, Beck J, et al. Chromosomal instability in cellfree DNA is a serum biomarker for prostate cancer. Clin Chem. 2015; 61(1):239-248.

90. Stephan C, Wilkosz J, Różański W, et al. Urinary thiosulfate as failed prostate cancer biomarker - an exemplary multicenter re-evaluation study. Clin Chem Lab Med. 2015;53(3):477-483.

91. Kalogirou C, Spahn M, Krebs M, et al. MIR-205 is progressively down-regulated in lymph node metastasis but fails as a prognostic biomarker in high-risk prostate cancer. Int J Mol Sci. 2013;14(11): 21414-21434
OncoTargets and Therapy

\section{Publish your work in this journal}

OncoTargets and Therapy is an international, peer-reviewed, open access journal focusing on the pathological basis of all cancers, potential targets for therapy and treatment protocols employed to improve the management of cancer patients. The journal also focuses on the impact of management programs and new therapeutic agents and protocols on

\section{Dovepress}

patient perspectives such as quality of life, adherence and satisfaction. The manuscript management system is completely online and includes a very quick and fair peer-review system, which is all easy to use. Visit http://www.dovepress.com/testimonials.php to read real quotes from published authors. 